\title{
Adaption Actions to Cope with Climate Change: Evidence from Farmers' Preferences on an Agrobiodiversity Conservation Programme in the Mediterranean Area
}

\author{
Ruggiero Sardaro *D, Nicola Faccilongo, Francesco Contò and Piermichele La Sala (D) \\ Department of Economics, University of Foggia, 71121 Foggia, Italy; nicola.faccilongo@unifg.it (N.F.); \\ francesco.conto@unifg.it (F.C.); piermichele.lasala@unifg.it (P.L.S.) \\ * Correspondence: ruggiero.sardaro@unifg.it
}

check for

updates

Citation: Sardaro, R.; Faccilongo, N.;

Contò, F.; La Sala, P. Adaption

Actions to Cope with Climate

Change: Evidence from Farmers'

Preferences on an Agrobiodiversity

Conservation Programme in the

Mediterranean Area. Sustainability

2021, 13, 5977. https://doi.org/

$10.3390 /$ su13115977

Academic Editor: Aled Jones

Received: 31 March 2021

Accepted: 24 May 2021

Published: 26 May 2021

Publisher's Note: MDPI stays neutral with regard to jurisdictional claims in published maps and institutional affiliations.

Copyright: (c) 2021 by the authors. Licensee MDPI, Basel, Switzerland. This article is an open access article distributed under the terms and conditions of the Creative Commons Attribution (CC BY) license (https:/ / creativecommons.org/licenses/by/ $4.0 /)$.

\begin{abstract}
The paper investigates the attitude of farmers to participate in an on-farm conservation programme based on the cultivation of vine landraces in Apulia, southern Italy, in place of the current commercial varieties, as an adaptation strategy to climate changes. The results, based on choice experiments and assessed through a latent class model, highlight a general interest of the regional farmers toward the biodiversity-based adaptation programme for coping with climate change. In particular, three classes of respondents were identified: (i) farmers operating on the whole regional territory and willing to cultivate up to $50 \%$ of their farm area with up to two landraces and compensation in line with the aid set by the regional rural programme; (ii) winegrowers of the intensive rural areas and willing to cultivate up to $25 \%$ of their farm with up to two landraces and a compensation greater than $200 \%$ compared to the aid of the regional rural programme; (iii) farmers operating in the intermediate rural areas and willing to cultivate up to $50 \%$ of their farm with up to three landraces and a compensation greater than $50 \%$ compared to the aid of the regional rural programme. Policymakers should calibrate adaption actions depending on rural areas, since economic, social, cultural, behavioural and cognitive barriers, as well as structural characteristics of farms, impact the farmers' attitudes toward measures aimed at coping with climate change.
\end{abstract}

Keywords: climate change; agrobiodiversity; vine landraces; choice experiment; Apulia

\section{Introduction}

Agriculture is one of the major sources of greenhouse gases (GHGs) but, at the same time, is one of the most susceptible sectors to the adverse impacts of climate change [1-4]. Alterations in climate affect abiotic (drought, excessive temperature and salinity in flooded areas) and biotic factors (diseases, pests, vectors, and weeds), which influence crop productivity. Low yields impact rural income and poverty levels, as well as on food prices and food security [5,6]. Furthermore, increasing temperatures cause varietal losses and negative consequences on pest resistance, water use and genetic resource [7]. Indeed, genetic diversity is crucial for breeding programs aimed at producing crops and livestock that are suitable to new climate conditions. Contrasting the effects of climate change and preserving agrobiodiversity are two of the nine specific objectives aimed at fostering a sustainable and competitive agricultural sector, so as to contribute to the "Farm to Fork" strategy in the ambit of the European Green Deal [8]. These recent policy developments, under the pressure of the COVID-19 pandemic, have become crucial in defining the general framework concerning a new vision of the sustainable agri-food system.

In order to reduce risks of negative impacts from climate change, to improve the resilience of socio-economic systems and to reduce vulnerabilities, mitigation and adaptation actions can be implemented [9]. Mitigation actions aim at decreasing emissions of GHGs or at enhancing carbon sinks, and benefit people that may be exposed to the negative effects of climate change. However, for significant outcomes, these actions require measures at 
national and international levels. Adaptation actions, instead, affect ecological, social and economic systems, and are mainly based on farm-scale interventions $[10,11]$. In operative terms, these actions concern changes in crop components (implementation of drought or heat resistant crops and varieties, and farming of resistant livestock breeds), in cultivation systems (use of innovative management practices, change of cropping calendar, switching to the multi-crop system, investment in irrigation equipment) and in livelihood (partial offfarm employment, on-farm non-agricultural activities, exit from the sector) [12]. Voluntary implementation of these actions at the farm level by self-interested farmers is possible if the private benefits of changes outweigh costs. In this case, benefits and costs are assessed through a comparison between present and expected conditions relating income, climate and policy settings [10]. However, adaptation actions often request actions involving public goods (agrobiodiversity, groundwater, etc.), whose allocation by the free market is not Pareto efficient (market failures). Furthermore, effective coping strategies in agriculture require systemic sectorial activities which should involve long-term planning and policy intervention to ensure positive effects on climate change on a regional scale. Thus, the role of policymakers is crucial in order to permit effective, efficient, well-informed and timely adaptation actions by private agents [13-15].

An adaptation action that is feasible at farm scale and able to grant positive sustainability outcomes across a wide range of climatic situations is the varietal shifting from modern and more productive ecotypes to landraces, i.e., local varieties and breeds of domesticated species that have adapted to the natural and cultural local environment [16]. In particular, plant landraces are often characterized by tolerance to increasing temperatures and prolonged dry spells, pest and disease resistance, and good commercial characteristics of produce. Thus, plant landraces can be managed by cultivation systems based on low levels of inputs, namely irrigation water, fertilizers, pesticides and fuel [17]. These characteristics of plant landraces derive from their genetic adaptation to the conditions of the local environment, so as to ensure stable yield, even under adverse conditions, but moderate yield under classic farming conditions. Indeed, over centuries, the environment allows the natural selection of plant varieties that are more adapted to the local climatic and soil characteristics. In these conditions, plant varieties based on a balance between vegetative and productive functions are favoured [18], so as to grow and to produce also through low levels of inputs. Furthermore, the value of landraces is not limited to the private profit of farmers, but concerns also several quasi-public benefits, i.e., positive externalities, in terms of quality production, environmental preservation, ecosystem services, food safety and cultural heritage [16,18-20].

However, landraces supply medium-low yield, thus their on-farm cultivation depends on the assessment of private net benefits [21], which derive from market conditions. In this connection, the market does not reward social benefits from the cultivation of landraces, and farmers have no private incentive or compensation for their use [22]. Consequently, more intensive cropping systems based on highly productive genotypes, but also characterized by high levels of inputs, are preferred. This approach is just one of several barriers that hinder the strategies aimed at implementing adaptation actions for climate change through the preservation of agrobiodiversity. In general, barriers to adaptation actions are "conditions or factors that render adaptation ineffective as a response to climate change and are largely insurmountable" [23]. Furthermore, in agriculture, there are structural, economic, social, cultural, technological, behavioural, cognitive and institutional barriers to adaptation strategies [24-26]. For example, barriers can be caused by inadequate information on the impacts of climate change, costs of adaptation, lack of technical options, financial constraints including access to credit, market failure, lack of insurance systems, etc. [27].

Adaptation actions in agriculture for coping with climate change are crucial strategies in the Mediterranean region, where temperature rise is higher than the current global warming trend, so as to exacerbate its negative impacts on farming, in terms of decreasing precipitation, droughts and higher risks of soil degradation and erosion [28]. To this aim, the cultivation of landraces that allows a lower use of water, fertilizers and pesticides is a 
valid approach for sustainable and resilient farming in Mediterranean areas [28]. However, it can be promoted only if the realignment of private and community interests is expected and the barriers are overcome. Payments for farming landraces could be a fair and proper solution to increase the real net return of farmers until their expected gain is reached. These payments could be used in specific programmes for on-farm preservation of agrobiodiversity based on the replacement of commercial varieties with landraces [29,30]. Such programmes should be based on (i) the assessment of financial resources for incentivizing the participation of farmers and (ii) the setting of proper measures by which different groups of farmers could participate in the programme. Indeed, farmers could exhibit different attitudes toward these programmes, and decision-makers should investigate this diversity, avoiding conflicts generated by non-fair actions.

The aim of the paper was twofold. First, we investigated farmers' attitudes to participate in on-farm conservation programmes based on the cultivation of vine landraces in Apulia, southern Italy, in place of the current commercial varieties, as an adaptation strategy to climate changes. The supposed adaption action was: planned (and not autonomous) because, for the scale of future climate change, autonomous adaptation will become inadequate; anticipatory (and not responsive); transformational (and not incremental), with the aim to change the structural attributes of the present regional wine growing and not to maintain the essence of existing one [31]. Secondly, we explored if the economic, social, cultural, behavioural and cognitive characteristics of farmers, as well as the structural characteristics of their farms, would affect the farmers' attitudes toward climate-friendly programmes.

This approach is important for understanding responses to climate change in the short run, but also for formulating regional long-run adaptation plans [32,33]. Indeed, there are factors that act as barriers to climate change adaptation actions and may prevent farmers from adopting climate-friendly practices. Therefore, policymakers should identify these barriers before designing new policies. According to the literature, there are several barrier types (structural, economic, social, cultural and behavioural barriers), sectoral and policy level, namely high cost of farm input, insufficient water resources, poor information on weather condition, inadequate access to credit and agricultural subsidies for adaptation actions, the effect of practices on production, the limited extent of climate policy, etc. [34,35]. Thus, this study explores the impacts of these barriers in joining climate change adaptation actions by farmers.

The paper contributes to the literature by investigating the attitudes of farmers and related barriers in adopting adaptation strategies for coping with climate change based on the conservation of Mediterranean landraces. In addition, it allows to verify the suitability of present adaption actions and it assists in the designing of future cost-effective onfarm programmes.

\section{Materials and Methods}

\subsection{Vine landraces in Apulia}

Apulia plays a leading role in the Italian wine sector. The region accounts for $12.7 \%$ of the national vineyard area (86,000 hectares, behind Sicily), $16.3 \%$ of the national grape production ( 1 million tonnes, behind Veneto) and $13.3 \%$ of the national wine production (5.6 million hectolitres, behind Veneto and Emilia-Romagna) [36]. The region produces a significant amount of high-quality wine. Indeed, $20 \%$ of production is labelled as Protected Designation of Origin (PDO) and $40 \%$ as Protected Geographical Indication (PGI), while the remaining $40 \%$ is table wine.

In the last decade, 50 regional vine landraces were recognized and further 118 were cited in bibliographies but have not yet been identified [37]. The Rural Development Programme (RDP) 2014-2020 of Apulia provided funds to farmers for promoting onfarm conservation and diffusion of regional vine landraces (sub-measure 10.1.4) [38]. These local and ancient varieties were inserted into a regional list (p. 699) and were classified into two classes of risk, on the basis of their genetic erosion risk concerning the 
speed of genetic variety loss, the difficulty in finding propagation material and the lack of demand. The compensation for farmers who undertook to cultivate vine landraces for at least five years was EUR $397 \mathrm{ha}^{-1}$ year $^{-1}$ for the risk-class-1 ecotypes (medium extinction risk) and EUR $417 \mathrm{ha}^{-1}$ year $^{-1}$ for the risk-class-2 ecotypes (high extinction risk). The compensation was assessed also on the additional costs and revenue losses consequent to the cultivation of landraces compared to commercial varieties. Moreover, the Apulia Region [39] provided funding to favour the restoration of specific local landraces characterized by high oenological and commercial value [40], and cultivated in extensive or semi-extensive systems, i.e., guyot and espalier systems. For these investments, aid amounted to $75 \%$ of restoration costs, including compensation for revenue loss, up to EUR $18.000 \mathrm{ha}^{-1}$.

\subsection{The Questionnaire}

The questionnaire consisted of three sections. The first collected the winegrowers' opinions concerning the impact of climate change on agriculture in general, and the possible use of adaption actions to cope with the negative impacts of climate change. At the end of the first section, respondents were informed about the benefits of biodiversitybased adaption actions on-farm and at the sector scale. In the first section, questions were inserted related to barriers that could affect/impede the adaptation actions based on agrobiodiversity programme, namely: structural (farm succession, age and structure); economic (lack of financial benefits, effects on production, costs of adoption, hidden and transaction costs, access to credit); sociocultural (cultural capital); behavioural and cognitive (beliefs about climate change, perceived long time horizons, uncertainty and risk management, competing pressures) barriers to adaptation [24-26].

In the second section, farmers were asked to make choices about a specific adaptation programme to cope with climate changes through the cultivation of vine landraces in place of highly productive varieties. In order to check the consistency between hypothetical and real choices [41] and assuming that they are theoretically identical, a supplementary question was inserted at the end of each choice task, where the responses were based on a scale from 0 (very unsure) to 5 (very sure) [42]. In this way, it was possible to account for the risk that respondents attached to each choice, thereby improving the predictive power of the survey [43]. In addition, such a question helped to highlight, in the choice task, alternatives that could provide similar utilities as considered substitutes by respondents.

Finally, the third section collected sociodemographic and farm characteristics of winegrowers (gender, age, education level, years of experience, farm size, credit access during last years, etc.). Face-to-face interviews lasting approximately $30 \mathrm{~min}$ were carried out from July to October 2020 at agricultural assistance centres. These are offices appointed for aiding agricultural operators in the management of their relationships with local, national, and European institutions through the production of administrative and economic documentation. Due to the essential nature of their services, the agricultural assistance centres are necessarily frequented by all regional agricultural operators, thus ensuring high representativeness of the sample. Interviews were conducted by the two authors, which were previously trained by an experienced interviewer, a Professor in the Department of Economics, at the University of Foggia.

\subsection{The CE Design}

The choice experiment (CE) is a stated preference method that allows respondents to express preferences among several alternatives concerning goods, services, plans, projects or programmes. Alternatives are defined by the combinations of attributes and respective levels. However, only a few alternatives are selected through an experimental design, and grouped so as to define the choice tasks. For each choice task, respondents are asked to choose the preferred alternative, i.e., the one giving the greatest relative utility [44].

The attributes and the levels were identified by a focus group. In stated preferences studies, it ensures design's quality and content validity to the survey [45] by the discus- 
sion of concepts and language, the explanation of scenarios, and the assessment of the information that respondents require to answer the valuation questions [46]. The focus group meeting was held in Foggia in May 2020 and involved: three regional winegrowers, operating in San Severo (Foggia province, in northern Apulia), Canosa di Puglia (BarlettaAndria-Trani province, in central Apulia) and Manduria (Lecce province, in southern Apulia), respectively; one agronomist; one academic expert in climate change (University of Bari); one academic expert in agrobiodiversity (University of Bari); one regional officer for rural development. These participants constituted a convenience (non-random) sample for their direct and indirect involvement in strategies for climate change. Furthermore, they were a varied and representative sample of stakeholders from different backgrounds [47]. The participants were invited two weeks before the meeting via email and were provided with a general description of the research and the topics of discussion [48].

The focus group meeting was designed to last approximately $60 \mathrm{~min}$ and was led by a moderator who facilitated and prompted conversation based on the following discussion topics: (i) impacts of climate changes in agriculture; (ii) adaptation strategies for coping with climate changes in regional winegrowing. In particular, a semi-structured interview was used for which three questions were formulated: (1) Are there negative and positive impacts of climate change in agriculture? (2) What strategies can be carried out to cope with negative climate change impacts? (3) Could the substitution of high productive varieties with landraces be a valid adaptation action to cope with negative climate change impacts? Finally, the focus group closed with an opportunity for the participants to debrief [49]. The participants in the meeting considered the cultivation of landraces for coping with climate change impacts as a valid adaptation strategy to be carried out in the Mediterranean area, enabling the generation of environmental, economic, social and cultural benefits. Indeed, the participants, as stakeholders directly involved in the scientific, technical, decisional and farming aspects of the Apulian winegrowing, recognized the changes in crop components as a crucial approach for reducing the demand of inputs (mainly irrigation water and fertilizers), and the key element of their outlook was based on the use of landraces, in line with other studies [50,51]. Thus, for the definition of the adaptation programme, stakeholders were interested in the use of landraces, but also on land occupation share, on the programme duration and on the avoidance option (Table 1). The monetary attribute was based on the compensation set in the Apulian RDP 2014-2020 for landraces preservation, thus, it was expressed as unit benefit that respondents are willing to accept (EUR ha ${ }^{-1}$ year $^{-1}$ ). In this regard, the welfare measure used for the $\mathrm{CE}$ was based on the concept of equivalent variation [52], i.e., the measurement of the amount of additional money required, before the change, to maintain the final level of utility. This monetary amount measures the Willingness to Accept (WTA), assessed when compensation is required. Indeed, WTA allows a faithful simulation of scenarios related to the RDP measures, so as to induce farmers to elicit their preferences concerning adaption actions for coping with climate change. This welfare measure can be less liable to strategic bias in CE studies [53,54], especially if respondents have a high degree of familiarity with the good at hand [55]. Moreover, in the stated preference methods, potential losers (in this case winegrowers) are asked their minimum WTA for their participation in a plan, programme or project $[56,57]$.

An important phase of CE study concerns the experimental design, which allows the selection of a suitable number of alternatives. An orthogonal design allowed the selection of 10 profiles, starting from 216 alternatives $\left(2^{2} \times 3^{2} \times 6^{1}\right)$, besides the "no choice" option. Thus, 5 choice tasks were assembled and shown to each respondent (Table 2). 
Table 1. Attributes and levels of the CE study (The first level is the reference one).

\begin{tabular}{ccc}
\hline Attributes & Definition & Levels \\
\hline Landrace & $\begin{array}{c}\text { Number of vine landraces cultivated in } \\
\text { the farm (n.) }\end{array}$ & $1,2,3$ \\
\hline Area & $\begin{array}{c}\text { Farm vineyard area allocated for the } \\
\text { programme (\%) }\end{array}$ & $25,50,100$ \\
\hline Duration & Duration of the programme (Years) & Y, 10 \\
\hline Avoidance & Option to leave the programme & Yes \\
\hline Compensation & $\begin{array}{c}\text { Regional payment to farmers for their } \\
\text { adherence to the programme } \\
\text { (EUR ha }{ }^{-1} \text { year }^{-1} \text { ) }\end{array}$ & $200,400,600,800,1000,1200$ \\
\hline
\end{tabular}

Table 2. Example of a choice set used for the interviews.

\begin{tabular}{cccc}
\hline Attributes & Option A & Option B & No Option \\
\hline Landrace & 3 & 1 & Neither A nor B. \\
Area & $100 \%$ & $25 \%$ & I do not want to \\
Duration & 10 years & 5 years & participate in the \\
Avoidance & No & Yes & regional programme \\
Compensation & EUR 1000 & EUR 200 & $\square$ \\
\hline My choice & $\square$ & $\square$ & $\square$ \\
\hline
\end{tabular}

In the choice sets the "no option" was inserted for simulating the mechanism of choice in purchase situations. Furthermore, the "pick-one" response format [58] was used for its simulation of real-life decision-making in capturing the first preference, and a 3alternative design (including the "no option") was adopted since it seems to generate more participation than a 2-alternative design [59]. The alternatives were unlabelled [60] in order to investigate the role of the attributes for the respondents and to increase their attention [61]. Based on this CE design, 400 interviews were planned. Overall, the study concerned a real problem (climate change) for whose attenuation a practical solution (cultivation of vine landraces) was proposed. Therefore, it can be assumed that the risk of biases related to CE was rather low [60].

A quantitative pretesting was carried out, so as to permit the assessment of the potential survey response rate and the item nonresponse rates, as well as the verification of the experimental design's suitability [62]. The quantitative pre-testing, based on the full version of the questionnaire, was carried out one month before the full survey and involved 28 respondents, who were drawn from the target population (regional winegrowers) at the same agricultural assistance centres where the full survey was conducted. The outcomes included a high rate of completed interviews (99.1\%), the full comprehension of the questions and proposed scenarios, the absence of any fatigue phenomenon, and a successful administration of the questionnaire to individuals with different experiences and knowledge levels. These findings confirmed that the respondents found the questionnaire and the related decision scenarios comprehensible and credible, thus ensuring a balanced and effective presentation of information [45].

\subsection{The Latent Class Model}

The CE approach is based on Lancaster's theory of value [63] and the Random Utility Model framework [64]. According to these approaches, CE assumes that the winegrower $i$ chooses the adaption programme $j$ among $n$ alternatives if $U_{i j}>U_{i n}$, i.e., the programme with the greatest utility $U$. However, only a share of the determinants of the individual utility is observable, or deterministic $\left(V_{i j}\right)$, while the second component is stochastic, or 
random $\left(\varepsilon_{i j}\right)$, including other factors not observable. Hence, the utility formula can be written as:

$$
U_{i j}=V_{i j}+\varepsilon_{i j}
$$

in which, the deterministic component is:

$$
V_{i j}=\beta_{i j k} \times X_{i j k}
$$

where $X_{i j k}$ is the vector of the $k$ utility determinants, and $\beta_{i j k}$ is the vector of coefficients indicating the marginal utility. Assuming that the error terms are independently and identically distributed (IID) with a Gumbel distribution, and relaxing the independence of the irrelevant alternatives (IIA) assumption by a discrete distribution of parameters [65,66], a latent class model (LCM) can be obtained $[67,68]$. This model clusters parameters in classes to catch the heterogeneity from unobservable preferences, thus allowing a sample segmentation and a segment-specific estimation of parameters. The segments highlight differences to the proposed programme among individual preferences, which are also based on socio-demographic and attitudinal characteristics, with crucial policy implications [69]. In other terms, the model captures preference heterogeneity across classes, but assumes homogeneous parameter estimates within each class [70].

The LCM assumes that winegrowers are implicitly sorted into $Q$ classes and, based on the logit form, the conditional choice probability of finding the winegrower $i$ in the class $q$ for the observed alternative $j$ is:

$$
\pi_{i j \mid q}=\frac{\exp \left(\beta_{q}^{\prime} x_{i j}\right)}{\sum_{q=1}^{Q} \exp \left(\beta_{q}^{\prime} x_{i j}\right)}
$$

where $x_{i}$ denotes a set of characteristics that are associated with class membership and $\beta_{q}$ are the specific class-related coefficients to estimate [71]. The conditional probability that the winegrower $i$ chooses the alternative $j$ is:

$$
\pi_{i j}=\sum_{q=1}^{Q} \pi_{i q} \pi_{i j \mid q}
$$

Finally, in order to best explain winegrowers' choices, the estimation of the parameter values is carried out through the maximization of the log-likelihood function:

$$
\ln L=\sum_{i=1}^{N} \ln \left[\sum_{q=1}^{Q} \pi_{i q}\left(\prod_{t=1}^{T_{i}} \pi_{i t \mid q}\right)^{y_{i j}}\right]
$$

where $y_{i j}$ is one or zero if the respondent $i$ chooses the alternative $j$ or not, respectively. Having obtained the coefficient estimates, the marginal rates of substitution between the attributes for each class can be calculated. If the utility is a linear function of all the attributes and a monetary attribute is included, the WTA for a change of the level of another attribute for the individuals in the latent class $q$ is calculated as follows:

$$
\operatorname{WTA}_{(A \mid q)}=\frac{\hat{\beta}_{(A \mid q)}}{\hat{\beta}_{(P \mid q)}}
$$

where $\hat{\beta}_{(A \mid q)}$ and $\hat{\beta}_{(P \mid q)}$ are the estimated coefficients, for the class $q$, of the non-monetary and monetary attributes, respectively. In order to relax the assumption that WTA is symmetrically distributed [72], 95\% confidence intervals for the WTA estimates were created by the parametric bootstrapping technique proposed by Krinsky and Robb [73]. It is based on the simulation of a distribution of 1000 observations for each WTA estimate. 
Results are analogous to those of the delta method. The number of classes was selected by the Log-Likelihood (LL), the Akaike Information Criterion (AIC), the Bayesian Information Criterion (BIC), and the Bozdogan AIC (AIC3). The analysis was carried out using NLOGIT 5.

\section{Results}

\subsection{Sample Characteristics}

There were 397 complete and coherent questionnaires (99.2\%), while 3 were discarded because the winegrowers always selected the "no option" alternative. The respondents' motivation was investigated by asking them to select a statement among a set of five assertions at the end of section two. The two statements these respondents selected to explain their behaviour or preferences were (1) I do not believe in climate change (2) and (2) Landraces are not a solution to the negative impacts of climate change (1). Due to aversion toward the thematic of the study, these respondents were excluded from the final analysis. An average score of 4.9 ( $\min 4.0 ; \max 5.0 ;$ std. dev. 0.6) was obtained from the complete questionnaires in response to the supplementary question inserted at the end of each choice task. This was in line with the pre-testing results (average score 4.9; min 4.0; max 5.0; std. dev. 0.7), thus excluding possible problems related to the uncertainty of the responses or to the similar utility of the alternatives. Consequently, no further use of this information was made in the final analysis.

The sample included, on average, 55-year-old and middle-educated male farmers owning small farms with a gross margin of EUR $7.000 \mathrm{ha}^{-1} \mathrm{yr}^{-1}$ (Table 3). Vineyards managed by the intensive farming system (so-called "Tendone" system) were $41 \%$, while farms growing vine landraces or carrying out organic practices were $14 \%$ and 19\%, respectively, to indicate that the regional winegrowing was mainly managed through semi-extensive practices. Most of the investigated farms sold wine grapes directly to wineries (89\%), so that value along the supply chain was mainly concentrated in its final stages (wineries and dealers). Just half of the farmers had successors (mainly sons) intentioned to continue the farm business in the future $(46 \%)$, showing problems related to generational change in the regional rural areas. This aspect, jointly with the relevant impact of part-time agriculture $(24 \%)$, showed the need for policies aimed at preserving the present winegrowing knowhow, which is related to economic but also social and environmental benefits. One farm out of two benefited from Common Agricultural Policy (CAP) aids (53\%), and one farm out of three had easy access to credit (36\%), so as to favour a high incidence of technical improvements in the farms. However, the access to clear and useful climate information in support of cultivation practices was considered difficult (79\%), and transition to landraces for coping with climate change requested high capital and management costs (79\%). Concerning the social and cultural factors playing an important role in farmers' decisions, most of the respondents believed that agricultural land should be protected for future generations (88\%), but also that agriculture was crucial for food security (71\%), so that the sector should be exempted from efforts to reduce emissions' impacts. The share of the winegrowers that believed in the truthfulness of climate change was high (97\%), but few farmers believed in the significance of impacts on climate change from their farming (39\%). Finally, 22\% of farmers were discouraged to take up climate-friendly practices due to the perceived long-term horizons, uncertainty and risk management about future climate change.

Where possible, the difference between the sampled and the regional farms was verified by the $t$-test, which highlighted a good adherence of the sample to the characteristics of the regional winegrowing, so as to ensure validity in the use of estimates for the planning of climate adaption actions at the regional scale. Furthermore, the spatial distribution of the sampled farms was coherent with the location of winegrowing farms in the regional provinces, as well as with their location in the rural areas defined within the framework of the European Rural Development Policy for 2014-2020 [74,75], namely rural areas with specialised intensive agriculture, intermediate rural areas (i.e., rural hill and mountain 
municipalities with higher population density and intermediate development) and rural areas with development problems.

Table 3. Descriptive statistics of the CE variables.

\begin{tabular}{|c|c|c|c|c|c|c|}
\hline Variable & Type of Barrier $^{\mathbf{a}}$ & Code & Mean & Std. Dev. & Min. & Max. \\
\hline Male (No/Yes) * & sc & Male & 0.86 & 0.72 & 0 & 1 \\
\hline Age (years) * & sc & Age & 55.19 & 26.83 & 18 & 77 \\
\hline Years of schooling (year) * & sc & Schooling & 7.44 & 8.26 & 3 & 18 \\
\hline Farm size (hectares) * & $\mathrm{s}$ & Size & 2.41 & 6.94 & 0.48 & 28.57 \\
\hline Gross margin (EUR ha $\left.{ }^{-1} \mathrm{yr}^{-1}\right)$ * & $\mathrm{s}$ & Margin & 7143.66 & $13,712.91$ & 4602.55 & $13,021.75$ \\
\hline $\begin{array}{l}\text { Tendone cultivation system } \\
\text { (No/Yes) }\end{array}$ & $\mathrm{s}$ & Tendone & 0.41 & 0.56 & 0 & 1 \\
\hline Landraces on farm (No/Yes) & $\mathrm{s}$ & Landraces & 0.14 & 0.25 & 0 & 1 \\
\hline Organic farming $(\mathrm{No} / \mathrm{Yes}) *$ & $\mathrm{~s}$ & Organic & 0.19 & 0.16 & 0 & 1 \\
\hline Possible farm successor (No/Yes) & $\mathrm{s}$ & Successor & 0.46 & 0.75 & 0 & 1 \\
\hline $\begin{array}{l}\text { Wine production and selling } \\
(\mathrm{No} / \mathrm{Yes})^{*}\end{array}$ & e & Wine & 0.11 & 0.19 & 0 & 1 \\
\hline Part-time (No/Yes) * & e & Part-time & 0.24 & 0.27 & 0 & 1 \\
\hline $\begin{array}{l}\text { CAP aids in past ten years } \\
\text { (No/Yes) }\end{array}$ & e & CAP & 0.53 & 0.49 & 0 & 1 \\
\hline $\begin{array}{l}\text { Access to credit in past ten years } \\
\text { (No/Yes) }\end{array}$ & e & Credit & 0.36 & 0.29 & 0 & 1 \\
\hline $\begin{array}{l}\text { Easy access to climate information } \\
\text { (No/Yes) }\end{array}$ & e & Information & 0.21 & 0.35 & 0 & 1 \\
\hline Costs of adaptation (No/Yes) & $\mathrm{e}$ & Costs & 0.79 & 0.81 & 0 & 1 \\
\hline $\begin{array}{l}\text { Crop cultivated for generations } \\
\text { (No/Yes) }\end{array}$ & sc & Generations & 0.88 & 0.69 & 0 & 1 \\
\hline $\begin{array}{l}\text { Agriculture for food production } \\
\text { (No/Yes) }\end{array}$ & sc & Food & 0.71 & 0.52 & 0 & 1 \\
\hline $\begin{array}{l}\text { Believe in climate change } \\
\text { (No/Yes) }\end{array}$ & bc & Believe & 0.97 & 0.70 & 0 & 1 \\
\hline $\begin{array}{l}\text { Farmers contribute to climate } \\
\text { change (No/Yes) }\end{array}$ & $\mathrm{bc}$ & Contribute & 0.39 & 0.41 & 0 & 1 \\
\hline $\begin{array}{l}\text { Uncertainty about future climate } \\
\text { changes (No/Yes) }\end{array}$ & $\mathrm{bc}$ & Uncertainty & 0.52 & 0.59 & 0 & 1 \\
\hline Intensive rural area $(\mathrm{No} / \mathrm{Yes})$ * & & Intensive & 0.33 & 0.39 & 0 & 1 \\
\hline Intermediate rural area (No/Yes) * & & Intermediate & 0.48 & 0.51 & 0 & 1 \\
\hline $\begin{array}{l}\text { Rural areas with development } \\
\text { problems (No/Yes)* }\end{array}$ & & Problems & 0.19 & 0.27 & 0 & 1 \\
\hline $\begin{array}{l}\text { Northern Apulia (Foggia } \\
\text { province) }(\mathrm{No} / \mathrm{Yes}) *\end{array}$ & & $\mathrm{~F}$ & 0.16 & 0.21 & 0 & 1 \\
\hline $\begin{array}{l}\text { Central Apulia } \\
\text { (Barletta-Andria-Trani and Bari } \\
\text { provinces) (No/Yes) * }\end{array}$ & & BTB & 0.35 & 0.38 & 0 & 1 \\
\hline $\begin{array}{l}\text { Southern Apulia (Brindisi, Taranto } \\
\text { and Lecce provinces) (No/Yes)* }\end{array}$ & & BTL & 0.49 & 0.47 & 0 & 1 \\
\hline
\end{tabular}

a type of barriers: $\mathrm{s}=$ structural; e = economic; sc = sociocultural; bc = behavioural and cognitive. ${ }^{*}$ significance of mean at $5 \%$ or $1 \%$, compared to Agriculture National Census (2010), Istat (2019) and FADN (2019) data.

\subsection{CE Results}

A three-class LCM was selected since the LL, AIC, BIC, and AIC3 were minimised at three segments (Table 4).

The analysis highlights three groups of winegrowers (Table 5). The first (LCM1) accounts for $27.8 \%$ of the sample and includes respondents who accept to participate in the climate adaptation programme by cultivating up to two landraces on their properties, but on a fam share lower than $25 \%$ and for a duration of less than 10 years. The possibility to avoid participation in the programme is welcomed, and the negative alternative-specific constant (ASC) confirms a general willingness to agree to the programme, even if partially. 
Table 4. Fitting measures for the selection of the LCM's number of classes.

\begin{tabular}{ccccc}
\hline Model & Log-Likelihood & AIC $^{\mathbf{a}}$ & BIC $^{\mathbf{b}}$ & AIC3 $^{\mathbf{c}}$ \\
\hline MNL & -2146.88 & 4351.76 & 2233.65 & 4380.76 \\
LCM2 & -1819.04 & 3712.08 & 1929.74 & 3749.08 \\
LCM3 & -1715.41 & 3562.82 & 1912.88 & 3628.82 \\
LCM4 & -1742.77 & 3675.54 & 2027.01 & 3770.54 \\
LCM5 & -1781.35 & 3810.70 & 2152.35 & 3934.70 \\
\hline
\end{tabular}

a Akaike information criterion: $-2(\mathrm{LL}-\mathrm{P}) ;{ }^{\mathrm{b}}$ Bayesian information criterion: $-\mathrm{LL}+(\mathrm{P} / 2){ }^{*} \ln (\mathrm{N}) ;{ }^{\mathrm{c}}$ Modified Akaike information criterion (Bozdogan AIC): $-2 \mathrm{LL}+3 \mathrm{P}$.

Table 5. Latent Class Model estimates.

\begin{tabular}{|c|c|c|c|c|c|c|}
\hline \multirow{3}{*}{ Class Probability } & \multicolumn{2}{|c|}{ LCM1 } & \multicolumn{2}{|c|}{ LCM2 } & \multicolumn{2}{|c|}{ LCM3 } \\
\hline & \multicolumn{2}{|c|}{0.278} & \multicolumn{2}{|c|}{0.458} & \multicolumn{2}{|c|}{0.264} \\
\hline & Coeff. & Std. Err. & Coeff. & Std. Err. & Coeff. & Std. Err. \\
\hline \multicolumn{7}{|l|}{ Utility function } \\
\hline Landrace: 2 & 3.686 & $1.67^{* *}$ & 1.784 & $0.67^{* *}$ & 0.619 & $0.13^{* * *}$ \\
\hline Landrace: 3 & -2.054 & $0.81^{* *}$ & 2.965 & $1.06^{* *}$ & -1.277 & 0.96 \\
\hline Area: 50 & -0.705 & $0.15^{* * *}$ & 0.474 & $0.12^{* * *}$ & 0.322 & $0.06^{* * *}$ \\
\hline Area: 100 & -3.936 & $0.74^{* * *}$ & 0.170 & 0.14 & -1.319 & $0.50^{* *}$ \\
\hline Duration: 10 & -1.449 & $0.61 * *$ & 0.233 & 0.14 & 0.715 & 0.63 \\
\hline Avoidance: No & -0.482 & $0.11^{* * *}$ & -0.341 & $0.13^{* *}$ & 0.524 & 0.41 \\
\hline Compensation & 0.004 & $0.00^{* * *}$ & 0.005 & $0.00^{* * *}$ & 0.010 & $0.00^{* * *}$ \\
\hline ASC & -1.102 & $0.46^{* *}$ & -2.814 & $0.51 * * *$ & -1.706 & $0.69^{* *}$ \\
\hline \multicolumn{7}{|l|}{ Segment probability function } \\
\hline Constant & 0.360 & $0.15^{* *}$ & 0.251 & $0.05^{* * *}$ & & \\
\hline Male & 0.835 & $0.34 * *$ & 0.480 & 0.39 & & \\
\hline Schooling & 0.472 & 0.38 & 0.625 & $0.26^{* *}$ & & \\
\hline Size & 1.048 & $0.39 * *$ & -0.837 & $0.32 * *$ & & \\
\hline Margin & 1.274 & $0.52 * *$ & -0.951 & $0.40 * *$ & & \\
\hline Tendone & 1.536 & $0.59 * *$ & -0.582 & 0.35 & & \\
\hline Organic & -1.427 & $0.27^{* * *}$ & 0.681 & $0.25 * *$ & & \\
\hline Successor & 0.622 & $0.22 * *$ & 0.493 & 0.42 & & \\
\hline Wine & -1.375 & $0.52 * *$ & 0.228 & 0.13 & & \\
\hline Part-time & -0.949 & $0.35 * *$ & 0.581 & $0.22 * *$ & & \\
\hline CAP & 0.801 & 0.47 & 0.684 & $0.25^{* *}$ & & \\
\hline Credit & 0.616 & $0.25 * *$ & 0.228 & 0.16 & & \\
\hline Information & 0.473 & 0.34 & 0.326 & $0.12 * *$ & & \\
\hline Costs & 1.327 & $0.29^{* * *}$ & 0.684 & 0.50 & & \\
\hline Generations & 0.534 & 0.38 & 0.691 & $0.24 * *$ & & \\
\hline Food & 0.618 & $0.26^{* *}$ & 0.501 & 0.49 & & \\
\hline Believe & 0.489 & 0.36 & 0.615 & $0.14^{* * *}$ & & \\
\hline Contribute & 0.275 & 0.19 & 0.407 & $0.14^{* *}$ & & \\
\hline Uncertainty & 0.465 & $0.18^{* *}$ & 0.726 & 0.65 & & \\
\hline Intensive & 1.259 & $0.24^{* * *}$ & -0.822 & 0.64 & & \\
\hline Intermediate & -0.888 & $0.33^{* *}$ & 0.893 & $0.21^{* * *}$ & & \\
\hline Obs. & 1.985 & & & & & \\
\hline McFadden pseudo- $\mathrm{R}^{2}$ & 0.401 & & & & & \\
\hline
\end{tabular}

With reference to its socio-economic characteristics, the group includes male winegrowers operating in the intensive rural areas, with large farm size and upper gross margin. Vines are cultivated by the "Tendone" management system, which spread in the region starting from the $60 \mathrm{~s}$ and is characterized by intensive management of vineyards based on high quantities of inputs per hectare, i.e., irrigation water, pesticides and chemical fertilizers, while the organic farming is not carried out. The winegrowers do not sell wine 
directly on the market, carry on full-time agriculture, and can benefit from easy access to credit for farm structural improvements. Usually, these farmers aim at increasing the intensity of farm management, while reconversion for landraces requests significant costs of adaptation, and therefore can only be carried out on a small share of the farm. Farmers have successors (mainly sons) that intend to manage their own business in the future through intensive management systems, whose aim is mainly related to food security. Moreover, farmers perceive long time horizons, uncertainty and risk management for climate change, which all discourage them from taking up climate-friendly practices. In general, they do not take a clear position toward climate change (information and belief variables), probably due to both the recognized small responsibility of agriculture and the perceived uncertainty and risk management. The average WTAs for the significant attributes and levels are reported in Table 6, where the negative values indicate aversion toward the specific attribute and/or level. Indeed, the attributes and levels considered in the study generate different degrees of acceptance toward the adaptation programme, due to different impacts that such strategy can cause on the present types of farm management. Thus, the minimum WTA for the on-farm cultivation of two landraces is EUR $921 \mathrm{ha}^{-1}$ year ${ }^{-1}$ more than the present compensation, so that the total compensation expected is double compared to the present aid set by the regional RDP.

Table 6. Average WTAs (EUR ha ${ }^{-1}$ year $^{-1}$ ) for the significant attributes and levels, with $95 \%$ confidence interval in parenthesis.

\begin{tabular}{cccc}
\hline & LCM1 & LCM2 & LCM3 \\
\hline Landrace: 2 & 921.50 & 356.80 & 63.16 \\
& $(663.481179 .52)$ & $(246.19467 .41)$ & $(50.5375 .80)$ \\
Landrace: 3 & -513.50 & 593.00 & \\
& $(-662.42-364.59)$ & $(397.31788 .69)$ & 32.86 \\
Area: 50 & -176.25 & 94.80 & $(25.6340 .09)$ \\
& $(-218.55-133.95)$ & $(76.79112 .81)$ & -134.59 \\
Area: 100 & -984.00 & & $(-177.66-91.52)$ \\
Duration: 10 & $(-1180.80-787.20)$ & & \\
Avoidance: No & $(-467.30-257.20)$ & & \\
& $(-145.81-95.20)$ & $(-88.66-47.74)$ & \\
\hline
\end{tabular}

The LCM2 group ( $45.8 \%$ of respondents) has a greater propensity toward participation in the adaptation programme. Indeed, it is willing to cultivate up to three landraces (confirmed by the negative ASC) on up to $50 \%$ of the farm area. The duration of the programme has no influence on its acceptance, while the possibility to avoid participation is even excluded. With reference to its socioeconomic characteristics, the group includes educated winegrowers operating in the intermediate rural areas, with a small farm size and gross margin. The respondents carry out organic farming, carry on part-time agriculture, and benefit from past CAP aids. They have easy access to climate information (mainly by web) and use them also to facilitate the cultivation practices. The respondents believe that agriculture benefits future generations and that climate change is an important phenomenon in which agriculture has a central role. The minimum WTA is EUR $357 \mathrm{ha}^{-1}$ year $^{-1}$ and EUR $593 \mathrm{ha}^{-1}$ year $^{-1}$ more than the present compensation, for the cultivation of two and three landraces, respectively. In particular, the minimum WTA is EUR $178 \mathrm{ha}^{-1} \mathrm{year}^{-1}$ and EUR $198 \mathrm{ha}^{-1}$ year $^{-1}$ per landrace, in presence of two and three landraces, respectively. Additional EUR $95 \mathrm{ha}^{-1}$ year $^{-1}$ are requested for using up to $50 \%$ of the farm area.

Finally, the reference class (LCM3) accounts for winegrowers (26.4\%) that are willing to cultivate up to two landraces on up to $50 \%$ of the farm area. In general, the adaption programme is accepted also by this group (negative and significant ASC), whose respondents present intermediate characteristics compared to the other two classes. Indeed, these winegrowers are middle-aged farmers with average gross margin and farm size, and 
operate in all the rural areas of the region. They carry out intensive or extensive management of vineyards, believe that agriculture benefits future generations and that climate change is a real and important phenomenon, in which agriculture has central responsibility. The minimum WTA is EUR $63 \mathrm{ha}^{-1}$ year $^{-1}$ more than the present compensation for the cultivation of two landraces. In particular, the minimum WTA is EUR $31 \mathrm{ha}^{-1}$ year $^{-1}$ per landrace, and an additional EUR $33 \mathrm{ha}^{-1} \mathrm{year}^{-1}$ is requested for using up to $50 \%$ of the farm area.

\section{Discussion and Conclusions}

The analysis highlighted a general interest of regional farmers toward the biodiversitybased adaptation programme for coping with climate change. In particular, the LCM3 farmers operate on the whole regional territory and are willing to cultivate up to $50 \%$ of their farm area with up to three landraces. The payment requested is essentially in line with the compensation set in the regional RDP 2014-2020. Furthermore, the analysis allowed to identify further two classes mainly focused on the intensive and intermediate rural areas. In the former one, winegrowers requested a compensation greater than $200 \%$ compared to the one set in the regional RDP, while in the latter one they stated a WTA that is circa 50\% more than the RDP aid. The WTAs reflect the different cost-opportunity and risk (negative impacts on production and high adaptation costs) related to the transition from intensive to extensive farming systems for participation in the agrobiodiversity-based adaption programme. This aspect has important consequences also on the share of the farm area devoted to the cultivation of landraces. Thus, in general, uncertainty related to climate change and to the economic performance of adaption actions are major reasons that farmers consider when making the decision to participate partially or fully in the programme by preferring mixed cultivation systems.

In general, the study suggests the need to create financial strategies tailored to different cultivation systems carried out on the regional territory. The setting of specific financial aid should be defined in the light of barriers concerning economic, social, cultural, behavioural and cognitive characteristics of farmers, as well as structural characteristics of farms. The impacts of barriers depend on local and specific aspects, so that each decision for new actions will be influenced by a unique combination of factors [26]. Studies supporting such consideration found that different adaption actions are implemented based on different groups of driving forces [76], so that factors able to universally explain the adoption of climate-friendly practices are unlikely to be detected.

The use of LCM allows just such investigation, since it clusters winegrowers into groups characterized by intra-group homogeneity and extra-group heterogeneity through the segment probability function. In this connection, the investigation of the considered barriers allowed to clearly highlight their impacts on choice preferences. Farmer's characteristics and farm's structure affect decision-making, which changes depending on rural areas. Indeed, in the intermediate rural areas based on a semi-extensive cultivation system (espalier system), the proposed programme was more accepted by male or female entrepreneurs characterized by a high schooling level and small farms with a low gross margin. These findings are in line with the literature, for which younger and well-educated farmers tend to show greater willingness to adopting recent and advanced technology, as well as environmentally friendly farming practices [77]. In contrast, male farmers operating in intensive areas and owning large and profitable farms intend to participate in a more weakened version of the programme in terms of landraces used and farm area devoted to their cultivation. This approach could be related to high adaption costs, as well as to perceived uncertainty and risk management. Furthermore, farm size allows to improve the efficiency of resources and to benefit from economies of scale [78], but this last aspect is not confirmed in the study since it depends also on the intensity level of the cultivation system. Therefore, in intensive areas, a large farm size is a necessary but not sufficient condition for accepting an adaptation programme. In semi-extensive areas, instead, small farm size does not hinder support to climate-friendly policies. 
Organic farming boosts participation in the adaptation programme in the intermediate areas, while it does not influence the preferences of winegrowers in the intensive rural areas since it is not widespread there. Furthermore, the presence of successors favours investments in adaptation actions that involve capital or infrastructural costs [79]. However, in this study, such factor influences partially the preference of winegrowers in the intensive rural areas, while it is irrelevant in the intermediate areas, probably due to the higher sensibility of respondents to the climate change issues regardless of future structural and management characteristics of farms.

Concerning the economic barriers, direct production and selling of wine in the intermediate areas can benefit from the adaptation programme through the development of specific climate-friendly wine labels. Indeed, this aspect can influence the farm performance thanks to market strategies that enable an increase in the value of the produce [80-82]. Part-time winegrowing also influences positively the participation in the programme in the intermediate areas, mainly due to the high schooling level of respondents, which operate in other economic sectors so as to increase their attitude toward climate-friendly investments and policies.

The study highlights that farms located in the intensive areas usually tend to benefit from easy access to credit, while farms in the intermediate areas are more inclined to request CAP aids. Overall, if the programme is associated with high implementation costs, access to credit and CAP aids are important solutions in favouring the participation in adaption actions. Indeed, in line with the literature, different forms of credit can improve the financial capacity of farms and increase the attitude of farmers toward climate-friendly practices characterized by lower yields or profits (landraces) [83].

Easy access to climate information and high costs of adaptation affects differently the participation in the adaption programme, depending on different management systems. In intermediate rural areas, climate information is used for cultivation practices (tillage, pest control, irrigation, etc.), also due to the higher schooling level of winegrowers. The availability of climate data, mainly over the internet, allows such respondents to improve the management performance of their own farms, makes winegrowers aware of climate changes over years, allows them to assess directly their impact on crops, and favours the participation in the programme. On the contrary, high adaption costs (capital and opportunity costs) negatively influence the participation in the programme in the intensive areas. Such an effect can be amplified by the lack of financial capacity for implementing climate-friendly practices, so as to impede their adoption by farmers [84].

Finally, concerning the social, cultural, behavioural and cognitive barriers, in intermediate rural areas, farmers show higher emotional or cultural attachments to land. Thus, climate-friendly land uses are boosted to protect land for future generations [85]. Furthermore, the same respondents believe that climate change is a real and actual phenomenon, and that they contribute to its impacts by farming. Such awareness boosts their participation in the programme. On the contrary, in intensive rural areas, winegrowers argue that agriculture addresses food security, so as to exempt it from efforts and policies for emission reduction [86]. Furthermore, they perceive long time horizons, uncertainty and risk management related to climate change, so as to discourage the uptake of full climate-friendly practices.

The study highlights the possibility of defining specific climate-friendly programmes in agriculture such as the preservation of grape landraces. However, the results show also that tailored measures should be defined on the basis of several factors concerning the social, economic, cultural, behavioural and cognitive characteristics of farmers, as well as the structural characteristics of farms $[87,88]$. In turn, the involvement and incidence of these barriers vary on the basis of the intensity level of the rural areas, so that each different rural area is characterized by a specific combination of factors influencing the participation in the proposed programme. Thus, policymakers should consider the wide heterogeneity of preferences among specific areas in order to improve the efficiency and effectiveness of measures through targeted interventions. 
According to the outcomes, a proper programme for coping with climate change through the preservation of the regional agrobiodiversity should allow (i) the development of new markets able to point out the characteristics of landrace produce, so as to ensure higher profits to winegrowers in the long run, also by creating and promoting climatefriendly labels [89]; (ii) the involvement of farmers in winemaking and wine selling in order to benefit from shorter supply chains; (iii) the definition of policies for generational change and technical information on climate change, so as to ensure better knowledge on its impacts in agriculture and on climate-friendly farming; (iv) the assistance to farmers relating to technological, managerial, economic and administrative aspects concerning the farming of vine landraces.

These aspects could contribute to making regional winegrowing more resilient to the negative impacts of climate change in the Mediterranean region. Furthermore, they could favour the diffusion of the local and historic varieties on a regional scale, so as to boost a new vision of the sustainable agri-food system in the post-Covid-19 era and in the framework of the "Farm to Fork" strategy. Benefits concern widespread welfare for all the actors of the wine supply chain, in terms of higher profits for farmers, better food security and safety for consumers, improved climate conditions and preservation of cultural values for the community.

Author Contributions: Conceptualization, R.S., N.F., F.C. and P.L.S.; methodology, R.S., N.F. and P.L.S.; software, R.S., N.F. and P.L.S.; validation, R.S., N.F. and P.L.S.; formal analysis, R.S., N.F. and P.L.S.; investigation, R.S., N.F. and P.L.S.; resources, R.S., N.F., F.C. and P.L.S.; data curation, R.S., N.F. and P.L.S.; writing - original draft preparation, R.S., N.F. and P.L.S.; writing-review and editing, R.S., N.F., F.C. and P.L.S.; visualization, R.S., N.F., F.C. and P.L.S.; supervision, R.S., N.F., F.C. and P.L.S.; project administration, R.S., N.F., F.C. and P.L.S.; funding acquisition, R.S., N.F., F.C. and P.L.S. All authors have read and agreed to the published version of the manuscript.

Funding: Published with a contribution from $5 \times 1000$ IRPEF funds in favour of the University of Foggia, in memory of Gianluca Montel.

Institutional Review Board Statement: Not applicable.

Informed Consent Statement: Informed consent was obtained from all subjects involved in the interviews.

Data Availability Statement: Data will be available on request from the authors.

Conflicts of Interest: The authors declare no conflict of interest.

\section{References}

1. Huang, J.K.; Wang, Y.J. Financing Sustainable Agriculture under Climate Change. J. Integr. Agric. 2014, 13, 698-712. [CrossRef]

2. Banna, H.; Afroz, R.; Masud, M.M.; Rana, M.S.; Koh, E.H.; Ahmad, R. Financing an efficient adaptation programme to climate change: A contingent valuation method tested in Malaysia. Cah. Agric. 2016, 25, 25003. [CrossRef]

3. Thuiller, T.; Lavorel, S.; Araújo, M.B.; Sykes, M.T.; Prentice, I.C. Climate change threats to plant diversity in Europe. Proc. Natl. Acad. Sci. USA 2005, 102, 8245-8250. [CrossRef] [PubMed]

4. Sardaro, R.; La Sala, P.; Roselli, L. How does the land market capitalize environmental, historical and cultural components in rural areas? Evidence from Italy. J. Environ. Manag. 2020, 269, 110776. [CrossRef]

5. Esham, M.; Garforth, C. Agricultural adaptation to climate change: Insights from a farming community in Sri Lanka. Mitig. Adapt. Strateg. Glob. Change 2013, 18, 535-549. [CrossRef]

6. Sardaro, R.; De Pascale, G.; Ingrao, C.; Faccilongo, N. Latent relationships between environmental impacts of cultivation practices and land market: Evidences from a spatial quantile regression analysis in Italy. J. Clean. Prod. 2021, 279, 123648. [CrossRef]

7. Thornton, P.K.; Van de Steeg, J.; Notenbaert, A.; Herrero, M. The impacts of climate change on livestock and livestock systems in developing countries: A review of what we know and what we need to know. Agric. Syst. 2009, 101, 113-127. [CrossRef]

8. European Commission. Proposal for a REGULATION OF THE EUROPEAN PARLIAMENT AND OF THE COUNCIL Establishing Rules on Support for Strategic Plans to be Drawn up by Member States under the Common Agricultural Policy (CAP Strategic Plans) and Financed by the European Agricultural Guarantee Fund (EAGF) and by the European Agricultural Fund for Rural Development (EAFRD) and Repealing Regulation (EU) No 1305/2013 of the European Parliament and of the Council and Regulation (EU) No 1307/2013 of the European Parliament and of the Council (COM/2018/392 Final). 2018. Available online: https:/ / eur-lex.europa.eu/legal-content/EN/TXT/?uri=COM\%3A2018\%3A392\%3AFIN (accessed on 7 May 2021). 
9. Adger, W.N.; Pulhin, J.M.; Barnett, J.; Dabelko, G.D.; Hovelsrud, G.K.; Levy, M.; Oswald Spring, Ú; Vogel, C.H. Human security. In Climate Change: Impacts, Adaptation, and Vulnerability. Part A: Global and Sectoral Aspects; Field, C.B., Barros, V.R., Dokken, D.J., Mach, K.J., Mastrandrea, M.D., Bilir, T.E., Chatterjee, M., Ebi, K.L., Estrada, Y.O., Genova, R.C., et al., Eds.; Cambridge University Press: Cambridge, UK; New York, NY, USA, 2014; pp. 755-791.

10. Ignaciuk, A. Adapting Agriculture to Climate Change: A Role for Public Policies. In OECD Food, Agriculture and Fisheries Papers, No. 85; OECD Publishing: Paris, France, 2015.

11. Sardaro, R.; Fucilli, V.; Acciani, C. Measuring the value of rural landscape in support of preservation policies. Sci. Reg. 2015, 14, 125-138.

12. Jarvis, A.; Lau, C.; Cook, S.; Wollenberg, E.; Hansen, J.; Bonila, O.; Challinor, A. An integrated adaptation and mitigation framework for developing agricultural research: Synergies and trade-offs. Exp. Agric. 2011, 47, 185-203. [CrossRef]

13. Hallegatte, S.; Lecocq, F.; Perthuis, C. Designing Climate Change Adaptation Policies. An Economic Framework; Policy Research Working Paper 5568; The World Bank: Washington, DC, USA, 2011.

14. OECD. Farmer Behaviour, Agricultural Management and Climate Change; OECD Publishing: Paris, France, 2012.

15. Petrillo, F.; Sardaro, R. Urbanizzazione in chiave neoliberale e progetti di sviluppo a grande scala. Sci. Reg. 2014, 13, 125-134. [CrossRef]

16. Pascual, U.; Jackson, L.E.; Drucker, A.G. Economics of agrobiodiversity. In Encyclopedia of Biodiversity, 2nd ed.; Academic Press: New York, NY, USA, 2013; pp. 31-44.

17. Jackson, L.E.; Brussaard, L.; de Ruiter, P.C.; Pascual, U.; Perrings, C.; Bawa, K. Agrobiodiversity. In Encyclopedia of Biodiversity, 2nd ed.; Academic Press: New York, NY, USA, 2013; pp. 126-135.

18. Camacho, V.T.C.; Maxted, N.; Scholten, M.; Ford-Lloyd, B. Defining and Identifying Crop Landraces. Plant Genet. Res. 2005, 3 , 373-384.

19. Sardaro, R.; Grittani, R.; Scrascia, M.; Pazzani, C.; Russo, V.; Garganese, F.; Porfido, C.; Diana, L.; Porcelli, F. The Red Palm Weevil in the city of Bari: A first damage assessment. Forests 2018, 9, 452. [CrossRef]

20. Sardaro, R.; La Sala, P. New value to wool: Innovative garments for preservation of sheep landraces in Italy. Animals 2021, 11, 731. [CrossRef]

21. Pascual, U.; Perrings, C. Developing incentives and economic mechanisms for in situ biodiversity conservation in agricultural landscapes. Agric. Ecos. Envir. 2007, 121, 256-268. [CrossRef]

22. Meinard, Y.; Grill, P. The economic valuation of biodiversity as an abstract good. Ecol. Econ. 2011, 70, 1707-1714. [CrossRef]

23. IPCC. Impacts, Adaptation and Vulnerability —Contribution of Working Group II to the Fourth Assessment Report of the Intergovernmental Panel on Climate Change; Cambridge University Press: Cambridge, UK, 2007.

24. Masud, M.M.; Azam, M.N.; Mohiuddin, M.; Banna, H.; Akhtar, R.; Alam, A.S.A.F.; Begum, H. Adaptation barriers and strategies towards climate change: Challenges in the agricultural sector. J. Clean. Prod. 2017, 156, 698-706. [CrossRef]

25. Wreford, A.; Ignaciuk, A.; Gruère, G. Overcoming barriers to the adoption of climate-friendly practices in agriculture. In $O E C D$ Food, Agriculture and Fisheries Papers, No. 101; OECD Publishing: Paris, France, 2017.

26. Sardaro, R.; Faccilongo, N.; Roselli, L. Wind farms, farmland occupation and compensation: Evidences from landowners' preferences through a stated choice survey in Italy. Energy Policy 2019, 133, 110885. [CrossRef]

27. Dasgupta, P.; Morton, J.F.; Dodman, D.; Karapinar, B.; Meza, F.; Rivera-Ferre, M.G.; Toure Sarr, A.; Vincent, K.E. Rural areas. In Climate Change: Impacts, Adaptation, and Vulnerability. Part A: Global and Sectoral Aspects; Field, C.B., Barros, V.R., Dokken, D.J., Mach, K.J., Mastrandrea, M.D., Bilir, T.E., Chatterjee, M., Ebi, K.L., Estrada, Y.O., Genova, R.C., et al., Eds.; Cambridge University Press: Cambridge, UK; New York, NY, USA, 2014; pp. 613-657.

28. Cramer, W.; Guiot, J.; Fader, M.; Garrabou, J.; Gattuso, J.-P.; Iglesias, A.; Lange, M.A.; Lionello, P.; Lla-sat, M.C.; Paz, S.; et al. Climate change and interconnected risks to sustainable development in the Mediterranean. Nat. Clim. Chang. 2018, 8, 972-980. [CrossRef]

29. Drucker, A.G.; Ramirez, M. Payments for agrobiodiversity conservation services: An overview of Latin American experiences, lessons learned and upscaling challenges. Land Use Policy 2020, 99, 104810. [CrossRef]

30. Rocchi, L.; Paolotti, L.; Cortina, C.; Boggia, A. Conservation of landrace: The key role of the value for agrobiodiversity conservation. An application on ancient tomatoes varieties. Agric. Agric. Sci. Proc. 2016, 8, 307-316. [CrossRef]

31. Kates, R.W.; Travis, W.R.; Wilbanks, T.J. Transformational adaptation when incremental adaptation climate change insufficient. Proc. Natl. Acad. Sci. USA 2012, 109, 7156-7161. [CrossRef]

32. Wreford, A.; Moran, D.; Adger, N. Climate Change and Agriculture: Impacts, Adaptation and Mitigation; OECD: Paris, France, 2010.

33. Sardaro, R.; La Sala, P. The technical efficiency of the Apulian winegrowing farms with different irrigation water supply systems. Econ. Agro Aliment. 2020, 22, 10410.

34. Birkmann, J.; von Teichman, K. Integrating disaster risk reduction and climate change adaptation: Key challenges-scales, knowledge, and norms. Sustain. Sci. 2010, 5, 171-184. [CrossRef]

35. Jones, L.; Boyd, E. Exploring social barriers to adaptation: Insights from Western Nepal. Glob. Environ. Chang. 2011, 21, 1262-1274. [CrossRef]

36. ISTAT. 2020. Available online: https:/ / www.istat.it/it/agricoltura?dati (accessed on 7 May 2021).

37. INEA. La Biodiversità Delle Colture Pugliesi; Istituto Nazionale di Economia Agraria: Roma, Italy, 2013. 
38. Apulia Region. Rural Development Programme 2014-2020. 2015. Available online: http:/ /www.reterurale.it/flex/cm/pages / ServeBLOB.php/L/IT/IDPagina/15122 (accessed on 7 May 2021).

39. BURP, Bollettino Ufficiale Della Regione Puglia n. 5 del 21 January 2016. 2016. Available online: http:/ / burp.regione.puglia.it/ documents/10192/4845000/N5_21_01_16.pdf/b83bc318-796d-44a4-8609-6abdc7b25a16 (accessed on 7 May 2021).

40. BURP, Bollettino Ufficiale Della Regione Puglia n. 16 del 31 January 2013. 2013. Available online: http:/ / burp.regione.puglia.it/ documents/10192/4849781/N16_31_01_13.pdf/ee7cb978-4505-4bf9-a828-417b3921abff (accessed on 7 May 2021).

41. Hensher, D.A.; Rose, J.M.; Beck, M.J. Are there specific design elements of choice experiments and types of people that influence choice response certainty? J. Choice Model. 2012, 5, 77-97. [CrossRef]

42. Brouwer, R.; Dekker, T.; Rolfe, J.; Windle, J. Choice certainty and consistency in repeated choice experiments. Environ. Res. Econ. 2010, 46, 93-109. [CrossRef]

43. Romy, G.; Bliemer, M.; Ballweg, J. Design considerations of a choice experiment to estimate likely participation by north Australian pastoralists in contractual biodiversity conservation. J. Choice Model. 2014, 10, 34-45.

44. Hensher, D.A.; Rose, J.M.; Greene, W.H. Applied Choice Analysis, 2nd ed.; Cambridge University Press: Cambridge, UK, 2015.

45. Johnston, R.J.; Boyle, K.J.; Adamowicz, W.; Bennett, J.; Brouwer, R.; Cameron, T.A.; Hanemann, W.M.; Hanley, N.; Ryan, M.; Scarpa, R.; et al. Contemporary Guidance for Stated Preference Studies. J. Assoc. Environ. Res. Econom. 2017, 4, 319-405. [CrossRef]

46. Coast, J.; McDonald, R.; Baker, R. Issues arising from the use of qualitative methods in health economics. J. Health Serv. Res. Policy 2004, 9, 171-176. [CrossRef]

47. Quick, K.; Zhao, Z. Suggested Design and Management Techniques for Enhancing Public Engagement in Transportation Policymaking. University of Minnesota Center for Transportation Studies Retrieved from the University of Minnesota Digital Conservancy. 2011. Available online: https:/ / conservancy.umn.edu/handle/11299/116934 (accessed on 30 January 2021).

48. Stewart, D.W.; Shamdasani, P.N. Focus Groups: Theory and Practice; Sage Publications: Thousand Oaks, CA, USA, 2014.

49. Bloor, M. Focus Groups in Social Research; Sage Publications: Thousand Oaks, CA, USA, 2001.

50. Vasconcelos, A.C.F.; Bonatti, M.; Schlindwein, S.L.; D'Agostini, L.R.; Homem, L.R.; Nelson, R. Landraces as an adaptation strategy to climate change for smallholders in Santa Catarina, Southern Brazil. Land Use Policy 2013, 34, 250-254. [CrossRef]

51. Veteläinen, M.; Negri, V.; Maxted, N. A European strategic approach to conserving crop landraces. In European Landraces: On-farm Conservation, Management and Use. Biodiversity Technical Bulletin No. 15; Veteläinen, M., Negri, V., Maxted, N., Eds.; Biodiversity International: Rome, Italy, 2009; pp. 305-325.

52. Hicks, J.R. The four consumer's surpluses. Rev. Econ. Stud. 1943, 11, 31-41. [CrossRef]

53. Burton, M. Inducing Strategic bias and Its Implications for Choice Modelling Design; Research Report n. 61; Australian National University: Canberra, Australia, 2010.

54. Schläpfer, F.; Fischhoff, B. Task familiarity and contextual cues predict hypothetical bias in a meta-analysis of stated preference studies. Ecol. Econ. 2012, 81, 44-47. [CrossRef]

55. Brennan, N.; Van Rensburg, T.M. Wind farm externalities and public preferences for community consultation in Ireland: A discrete choice experiments approach. Ener. Pol. 2016, 94, 355-365. [CrossRef]

56. Tunçel, T.; Hammitt, J. A new meta-analysis on the WTP/WTA disparity. J. Environ. Econ. Manag. 2014, 68, 175-187. [CrossRef]

57. Horowitz, J.; McConnell, K. A Review of WTA/WTP Studies. J. Environ. Econ. Manag. 2002, 44, 426-447. [CrossRef]

58. Flynn, T.N.; Louviere, J.J.; Peters, T.J.; Coast, J. Best-worst scaling: What it can do for health care research and how to do it. J. Health Econ. 2007, 26, 171-189. [CrossRef] [PubMed]

59. Rolfe, J.; Bennett, J. The impact of offering two versus three alternatives in choice modelling experiments. Ecol. Econ. 2009, 68, 1140-1148. [CrossRef]

60. Louviere, J.J.; Hensher, D.A.; Swait, J.D. Stated Choice Methods: Analysis and Applications; Cambridge University Press: Cambridge, UK, 2000.

61. De Bekker-Grob, E.W. Discrete Choice Experiments in Health Care: Theory and Applications; Erasmus University: Rotterdam, The Netherlands, 2009.

62. Vermeulen, B.; Goos, P.; Scarpa, R.; Vandebroek, M. Bayesian conjoint choice designs for measuring willingness to pay. Environ. Res. Econom. 2011, 48, 129-149. [CrossRef]

63. Lancaster, K.J. A new approach to consumer theory. J. Polit. Econ. 1966, 74, 132-157. [CrossRef]

64. McFadden, D. Conditional logit analysis of qualitative choice behaviour. In Frontiers in Econometrics; Zarembka, P., Ed.; Academic Press: New York, NY, USA, 1973; pp. 105-142.

65. Greene, W.H. NLOGIT Version 5-Reference Guide; Econometric Software: Plainview, NY, USA, 2012.

66. Train, K.E. Discrete Choice Methods with Simulation, 2nd ed.; Cambridge University Press: Cambridge, UK, 2009.

67. Lazarsfeld, P.F.; Henry, N.W. Latent Structure Analysis; Houghton Mill: Boston, MA, USA, 1968.

68. Goodman, L.A. The analysis of systems of qualitative variables when some of the variables are unobservable. Part I: A modified latent structure approach. Am. J. Soc. 1974, 79, 1179-1259. [CrossRef]

69. Wedel, M.; Kamakura, W.A. Market Segmentation: Concepts and Methodological Foundations; Kluwer Academic Publishers: Boston, MA, USA, 2000.

70. Greene, W.H.; Hensher, D.A. A latent class model for discrete choice analysis: Contrasts with mixed logit. Transp. Res. Part B Meth. 2003, 37, 681-698. [CrossRef] 
71. Boxall, P.C.; Adamowicz, W.L. Understanding heterogeneous preferences in random utility models: A latent class approach. Environ. Res. Econ. 2002, 23, 421-446. [CrossRef]

72. Hole, A.R. A comparison of approaches to estimating confidence intervals for willingness to pay measures. Health Econ. 2007, 16, 827-840. [CrossRef] [PubMed]

73. Krinsky, I.; Robb, A.L. On approximating the statistical properties of elasticities. Rev. Econ. Stat. 1986, 68, 715-719. [CrossRef]

74. European Commission. Overview of CAP Reform 2014-2020. Agricultural Policy Perspectives Brief N ${ }^{\circ}$. 2013. Available online: https:/ / ec.europa.eu/info/sites/info/files/food-farming-fisheries/farming/documents/agri-policy-perspectives-brief05_en.pdf (accessed on 7 May 2021).

75. Noack, E.M.; Schüler, S. Rural development and human well-being: Do pillar-II-programmes take into account ecosystem services? A study in Lower Saxony, Germany. Environ. Sci. Policy 2020, 106, 191-200. [CrossRef]

76. Van Dijl, E.A.; Grogan, K.A.; Borisova, T. Determinants of adoption of drought adaptations among vegetable growers in Florida. J. Soil Water Conserv. 2015, 70, 218-231. [CrossRef]

77. Karali, E.; Brunner, B.; Doherty, R.; Hersperger, A.; Rounsevell, M. Identifying the factors that influence farmer participation in environmental management practices in Switzerland. Hum. Ecol. 2014, 42, 951-963. [CrossRef]

78. Davis, J.; Caskie, P.; Wallace, M. Economics of farmer early retirement policy. Appl. Econ. 2009, 41, 35-43. [CrossRef]

79. Fischer, H.; Burton, R.J.F. Understanding Farm Succession as Socially Constructed Endogenous Cycles. Sociol. Rural. 2014, 54, 417-438. [CrossRef]

80. Giacomarra, M.; Crescimanno, M.; Vrontis, D.; Pastor, L.M.; Galati, A. The ability of fish ecolabels to promote a change in the sustainability awareness. Mar. Policy 2020, 123, 104292. [CrossRef]

81. Lim, K.H.; Reed, M. Do ecolabels cheapen wines? J. Clean. Prod. 2020, 245, 118696. [CrossRef]

82. Giannoccaro, G.; Carlucci, D.; Sardaro, R.; Roselli, L.; De Gennaro, B.C. Assessing consumer preferences for organic vs eco-labelled olive oils. Org. Agric. 2019, 9, 483-494. [CrossRef]

83. Baumgart-Getz, A.; Prokopy, L.S.; Floress, K. Why farmers adopt best management practice in the United States: A meta-analysis of the adoption literature. J. Environ. Manag. 2012, 96, 17-25. [CrossRef] [PubMed]

84. Sánchez, B.; Álvaro-Fuentes, J.; Cunningham, R.; Iglesias, A. Towards mitigation of greenhouse gases by small changes in farming practices: Understanding local barriers in Spain. Mitig. Adapt. Strateg. Glob. Chang. 2014, 21, 995-1028. [CrossRef]

85. Eakin, H.; York, A.; Aggarwal, R.; Waters, S.; Welch, J.; Rubiños, C.; Smith-Heisters, S.; Bausch, C.; Anderies, J.M. Cognitive and institutional influences on farmers' adaptive capacity: Insights into barriers and opportunities for transformative change in central Arizona. Reg. Environ. Chang. 2015, 16, 801-814. [CrossRef]

86. Rosin, C. Food security and the justification of productivism in New Zealand. J. Rural Stud. 2013, 29, 50-58. [CrossRef]

87. Sardaro, R.; Bozzo, F.; Fucilli, V. High-voltage overhead transmission lines and farmland value: Evidences from the real estate market in Apulia, southern Italy. Energy Policy 2018, 119, 449-457. [CrossRef]

88. Acciani, C.; Sardaro, R. Perception of risk by electromagnetic fields in the context of power-line easement: Impact on agricultural land value. Aestimum 2014, 64, 39-55.

89. Martin, P.; Wishart, J.; Cromarty, A.; Chang, X. New markets and supply chains for Scottish Bere barley. In European Landraces: On-Farm Conservation, Management and Use-Biodiversity Technical Bulletin No. 15; Veteläinen, M., Negri, V., Maxted, N., Eds.; Biodiversity International: Rome, Italy, 2009; pp. 251-263. 